$<$ 原 著 $>$

$$
\text { インターフェロン治療例に打ける肝組織中 HCV-RNAの }
$$

\title{
変化と治療効果についての検討
}

\section{竹内 正勇*}

要 旨：インターフェロン(IFN) 療法時の肝組織中 HCV-RNA の動態と治療効果の関連を明 らかにするために，C型慢性肝炎患者30例を対象に IFN 前後の血中および肝組織中 HCV. RNA の測定を行った，治療前の HCV-RNA は血中では30例中29例(96.7\%), 肝組織中では測 定した14例すべてに陽性であったが，治療終了時には血中では 6 例(20\%)，肝組織中では11例 (36.7\%)に陽性であった。 また，治療前後の肝組織中ウイルス量は13例において測定され，1 例を除く全例に低下が認められた。一方, 治療効果との関連では, 治療終了時の肝組織中 HCVRNA 陽性例は全例再燃を認めた。しかし，治療終了時，血中・肝組織中とも HCV-RNA 陰性 であっても，著効は18例中 8例（44\%）のみであった，以上の結果から，IFN 終了時，血中で 陰性化しても肝組織中に HCV-RNA が残存する例があり，これらの症例では全例再然が認め られること，さらに肝組織中の HCV-RNA が消失しても再然する例が存在することが示され た.

索引用語： C 型慢性肝炎 インターフェロン療法 肝組織中 HCV-RNA

はじめに

近年, C 型慢性肝炎に対する治療としてインター フェロン (IFN) 療法が行われ, C 型肝炎ウイルス (HCV)RNAの持続陰性化など, その有効性が報告さ れてきた1で.これまでの検討において, HCV.RNAは 血清を材料として, polymerase chain reaction(PCR) 法, DNA probe法で定性的あるいは定量的に評価さ $れ^{\text {s -8) }}$, IFN 療法終了時の血中 HCV-RNA の陰性化率 は60８0\%以上と報告されている゙ ? . しかしながら， 治療終了後 6 力月では約 $50 \%$ HCV-RNAの再出現 を認めることが知られている5 こ この血中 $\mathrm{HCV}$. RNAが再出現する機序として，血中に測定法の感度 以下の HCV 粒子が存在している可能性や，血中には 存在していなくとも肝組織中に HCV が残存している 可能性等が考えられているが，IFN 療法時の肝組織中 HCV-RNA の推移についてはこれまで報告が少なく， 末だ不明な点が多く残されている，そこで，IFN 療法 時の肝組織中 HCV.RNAの動態を明らがするため に, 本研究では IFN 療法前後の肝組織中 HCV-RNA を定性的に，一部定量的に測定し，さらに，血清

Masayu TakeUChI*

"金沢大学第 1 内科

<受付日1994年 2 月21日 $>$ alanine aminotransferase（ALT）値から評価した治 療効果との関連についても検討した。

\section{対象と方法}

\section{1. 对象}

金讯大学医学部第 1 内科およびその関連病院におい て，第 2 世代の HCV 抗体陽性で組織学的に慢性肝炎 と診断され，IFN 療法を行った30例を対象とした。平

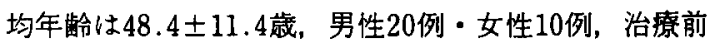

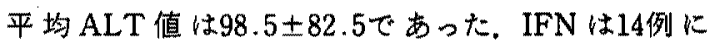
recombinant IFN- $\alpha$ (2a：4例，2b：10例）を，16例 にIFN. $\beta$ を用いた. IFN 投与方法は IFN- $\alpha$ 使用例で は6Megaunits (MU) 2 週連日投与後, 週 3 回14 22 週投与（総投与量336 480MU）上L, IFN- $\beta$ 使用例 では 8 週連日投与（総投与量336MU）とした。IFN 治 療効果は厚生省・難治性の肝炎調査研究班の判定基準 にしたがい，著効例 (excellent)・有効例 (good)・不 変あるいは悪化例（no response）に分けて評価した。 治療前の組織診断は chronic persistent hepatitis (CPH) 8 例 - chronic active hepatitis $(\mathrm{CAH}) 2 \mathrm{~A} 19$ 例・CAH2B 3 例であった. 血中 HCV-RNA は全例に おいて治療前後で測定し，肝組織中 HCV-RNA は14 例において治療前後で，16例において治療後にのみ娜 定した. 


\section{2. 血中 HCV-RNA の測定}

IFN 療法の直前お上び直後 1 週間以内に採血を行 い，測定までー40ㄷにて保存した．以前報告9したごと 〈，血清 $10 \mu l$ を用い，5'non coding 領域の合成 DNA (outer primer set: sense ; $5^{\prime}$-ACTCCACCATAGA TCACTCC-3' - antisense ; $5^{\prime}$-T TGTGCTCATGGTGCACGGTCTACG-3', inner primer set : sense : $5^{\prime}$-ATCACTCCCCTGTGAGGAACTACTG$3^{\prime} \cdot$ antisense ; $5^{\prime}$-TCATGGTGCACGGTCTACGAGACCT -3') primer とし, reverse transcription-nested PCR single tube 内にて行。 た. PCR 産物は agarose gel 電気泳動後 ethidium bromide 染色にて310bp バンドの検出を行った。また, 28 例において, Okamoto $5^{10}$ の方法に従い, core 領域に 設定したtype-specific primerを用いて HCVの genotype を判定した.

\section{3. 肝組織中 HCV-RNA の測定}

IFN 前の肝生検は治療開始 2 週間前までに施行乙 た. IFN 後の肝生検は27例においてて治療終了直前ある い、直後 5 日間以内に施行し，3例に战い,て治療終了 後10日から 2 週間で施行した。肝生検はVimSilverman 針あるいは Menghini 針を用い, 約 $5 \mathrm{~mm}$ 切 片を採取後即座に液体窒素あるいはドライフイスにて 凍結させ, 測定までー $70^{\circ} \mathrm{C}$ に保存した。肝組織中 $\mathrm{HCV}$. RNA の調整传 acid guanidium thiocyanate-phenol-

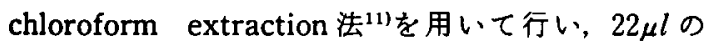
dietyl pyrocarbonate (DEPC) treated water $に て$ 溶 解後，半量を測定に用いた。 cDNAの合成には，調整 した RNA 溶液に outer primer set (血中 HCV-RNA の測定に用いたものと同一)を，それぞれ90pmolを加 之 $70^{\circ} \mathrm{C}$ にて 7 分間加熱後, 室温で 10 分間 anealing し, その後 ribonuclease inhibitor (Promega Biotech, Madison, WI, USA) 40units, $10 \mathrm{mM} \mathrm{dNTP} 2.5 \mu \mathrm{l}$, $100 \mathrm{mM}$ dithiothreitol $2.5 \mu l, \times 10$ reverse buffer $(30$ $\mathrm{mM} \mathrm{MgCl}, 500 \mathrm{mM}$ Tris-hydrochloric acid pH 8.3, $750 \mathrm{mM} \mathrm{KCl)} 2.5 \mu l$, avian myeloblastosis virus reverse transcriptase (Promega) 10units $42^{\circ} \mathrm{C}$ にて60分間反応した，反応後 Taq polymerase (Perkin Elmer Cetus, Norwalk, CT, USA) 5units, $x$ $10 \mathrm{Taq}$ buffer $\left(15 \mathrm{mM} \mathrm{MgCl}_{2}, 500 \mathrm{mM}\right.$ Trishydrochloric acid $\mathrm{pH} 8.3,750 \mathrm{mM} \mathrm{KCl}, 0.1 \% \mathrm{v} / \mathrm{w}$ gelatine) $7.5 \mu l, \mathrm{DEPC}$ treated water $67 \mu l$ を加光総 量を $100 \mu l$ とした後, $94^{\circ} \mathrm{C} て ゙ 3$ 分間加熱し，つついて programmable thermal cycler (Perkin Elmer Cetus)
を用いて $30 \mathrm{cycle}\left(94^{\circ} \mathrm{C} 1\right.$ 分間, $42^{\circ} \mathrm{C}, 1.5$ 分間, $72^{\circ} \mathrm{C} 3$ 分間）の first stage PCR 老行った。つついて反应 物 $10 \mu l$ を用いて, inner primer set を加光, first stage PCR と同様に25cycle の second stage PCR を行っ た. PCR 産物は $3 \%$ agarose gel にて電気泳動し, ethidium bromide 染色にて310bp パンドを検出すること により判定した。 盰組織中 HCV-RNA の定量には, 一 $70^{\circ} \mathrm{C}$ に保存した RNA を DEPC treated water にて希 秎し，その検出限界により $10^{0} \cdot 10^{1} \cdot 10^{3} \cdot 10^{5} \cdot 10^{7}$ 希䣋 以上の 5 段階で評価した。

\section{結果}

1. IFN 治療前後における血中および肝組織中 $\mathrm{HCV} \cdot \mathrm{RNA}$ の推移

\section{1) 治療前}

治療前の血中 HCV-RNA はCPH 1 例をのぞく全 例に陽性であった。一方，治療前の肝組織中 HCVRNA は血中 HCV-RNA 陰性であった 1 例を含め, 測 定した14例すべてが陽性であった（Table 1)。また， genotype 分類は, II 型20例 $(71.4 \%)$, III 型 2 例 (7.1\%)，IV型 2 例 $(7.1 \%)$ ，分類不能 4 例 (14.3\%) であった.

\section{2）治療終了時}

治療終了時の血中 HCV.RNA は30例中 6 例 $(20 \%)$ が陽性であった。一方, 肝組織中 HCV-RNA は，治療 前に陽性であった14例では 5 例 $(35.7 \%)$ ，治療後のみ 湘定した16例では 6 例 $(37.5 \%)$, 合計30例中11例 (36.7\%)が陽性であり，治療終了時の肝組織中 HCV. RNA 検出率は血中 HCV-RNA 検出率に比し高率で あったが，有意差は認められなかった。

3）治療終了時における血中と肝組織中の HCVRNA の関連

IFN 終了時の血中 HCV.RNA と肝組織中 HCV. RNAの関連について検討したところ, 血中 $\mathrm{HCV}$ RNA 陽性の 6 例中 5 例 (83.3\%) が肝組織中 HCV. RNA 陽性であり，一方，血中 HCV-RNA 陰性の24例 では， 6 例 (25\%) が肝組織中 HCV-RNA 陽性であっ た (Table 2).

4）治療前後における肝組織中 HCV-RNA 量の変 化

治療前後において肝組織中 HCV.RNA 量を定量し た13例の成績をFig. 1 に示す.治療前の肝組織中 HCV-RNA 量は $10^{1}$ 希䣋が 2 例, $10^{3}$ 希釈が 7 例, $10^{5}$ 希 釈が 2 例，107希釈以上が 2 例であった。治療後には8 例 (61.5\%)におい.て肝組織中 HCV.RNAの陰性化を 
Table 1 Change of liver histology and presence of HCV-RNA in serum and liver tissue before and after IFN therapy.

\begin{tabular}{|c|c|c|c|c|c|c|c|c|c|}
\hline \multirow{3}{*}{ Case } & \multirow{3}{*}{ IFN } & \multirow{3}{*}{ Response to IFN } & \multirow{2}{*}{\multicolumn{2}{|c|}{ Histology }} & \multirow{3}{*}{ Genotype } & \multicolumn{4}{|c|}{ HCV-RNA } \\
\hline & & & & & & \multicolumn{2}{|c|}{ serum } & \multicolumn{2}{|c|}{ liver } \\
\hline & & & before & after & & before & after & before & after \\
\hline 1 & $\alpha-2 a$ & excellent & CPH & $\mathrm{CPH}$ & $\mathrm{UC}$ & - & - & + & - \\
\hline 2 & $\alpha-2 b$ & excellent & CAH2A & NSC & UC & + & - & ND & - \\
\hline 3 & $\alpha-2 b$ & excellent & CAH2A & CAH2A & II & + & - & ND & - \\
\hline 4 & $\alpha-2 b$ & excellent & CAH2A & CAH2A & ND & + & - & ND & - \\
\hline 5 & $\alpha-2 b$ & excellent & CAH2A & CAH2A & ND & + & - & ND & - \\
\hline 6 & $\beta$ & excellent & CAH2A & CAH2A & II & + & - & + & - \\
\hline 7 & $B$ & excellent & $\mathrm{CPH}$ & CPH & II & + & - & ND & - \\
\hline 8 & $\beta$ & excellent & $\mathrm{CPH}$ & $\mathrm{CPH}$ & II & + & - & ND & - \\
\hline 9 & $\alpha-2 b$ & good & CAH2A & $\mathrm{CPH}$ & II & + & + & + & + \\
\hline 10 & $\alpha \cdot 2 b$ & good & CAH2A & CAH2A & II & + & + & ND & + \\
\hline 11 & $\beta$ & good & CAH2A & $\mathrm{CPH}$ & II & + & + & + & + \\
\hline 12 & $\beta$ & good & CAH2A & САH2A & II & + & - & ND & + \\
\hline 13 & $\beta$ & good & $\mathrm{CPH}$ & $\mathrm{CPH}$ & II & + & - & ND & + \\
\hline 14 & $\alpha \cdot 2 b$ & good & $\mathrm{CPH}$ & NSC & III & + & - & + & - \\
\hline 15 & $\beta$ & good & $\mathrm{CPH}$ & $\mathrm{CPH}$ & UC & + & - & ND & - \\
\hline 16 & $\beta$ & good & CAH2A & CAH2A & II & + & - & + & - \\
\hline 17 & $\alpha-2 a$ & no response & $\mathrm{CAH} 2 \mathrm{~A}$ & $\mathrm{CAH} 2 \mathrm{~A}$ & III & + & + & ND & + \\
\hline 18 & $\alpha-2 b$ & no response & CAH2A & CAH2A & IV & + & + & + & + \\
\hline 19 & $\alpha \cdot 2 \mathrm{a}$ & no response & $\mathrm{CPH}$ & $\mathrm{CPH}$ & II & + & + & + & - \\
\hline 20 & $\alpha \cdot 2 b$ & no response & CAH2A & $\mathrm{CPH}$ & II & + & - & + & + \\
\hline 21 & $\alpha-2 b$ & no response & CAH2A & $\mathrm{CPH}$ & II & + & - & ND & + \\
\hline 22 & $\beta$ & no response & CAH2B & CAH2B & II & + & - & ND & + \\
\hline 23 & $\beta$ & no response & CAH2B & $\mathrm{CAH} 2 \mathrm{~B}$ & II & + & - & + & + \\
\hline 24 & $\alpha-2 \mathrm{a}$ & no response & CAH2A & $\mathrm{CPH}$ & UC & + & - & + & - \\
\hline 25 & $A$ & no response & CAH2A & $\mathrm{CPH}$ & II & + & - & ND & - \\
\hline 26 & $\beta$ & no response & $\mathrm{CPH}$ & $\mathrm{CPH}$ & II & + & - & ND & - \\
\hline 27 & $\beta$ & no response & СAH2A & $\mathrm{CPH}$ & II & + & - & + & - \\
\hline 28 & $\boldsymbol{\beta}$ & no response & CAH2A & САH2A & II & + & - & + & - \\
\hline 29 & $\beta$ & no response & CAH2B & САH2B & II & + & - & + & - \\
\hline 30 & $\beta$ & no response & CAH2A & $\mathrm{CPH}$ & IV & + & - & ND & - \\
\hline
\end{tabular}

NSC, non-specific change; UC, unclassifiable; ND, not done.

Table 2 Relation ship between the presence of HCV.RNA in serum and in liver tissue at the end of IFN therapy.

\begin{tabular}{c|c|c}
\hline serum liver & + & - \\
\hline+ & $5(16.7 \%)$ & $1(3.3 \%)$ \\
\hline- & $6(20 \%)$ & $18(60 \%)$ \\
\hline
\end{tabular}

認め, 治療後にも HCV-RNA 陽性の 5 例では, $10^{\circ}$ 希釈 が 1 例, $10^{1}$ 希釈が 3 例, $10^{3}$ 希䣋が 1 例であった.なお, 治㞠前後の HCV.RNA 量の推移では，1例を除く全 例に减少が認められ，その差は有意であった（p= 0.0001 ).
5）治總了時の肝組䄉中 HCV-RNA 陰性例にお ける背寒因子の検討

治療終了時の肝組織中 HCV.RNA 陰性の背景因子 を検討した。平均年龄では，肝組織中 HCV-RNA 陰性

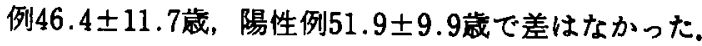
治療前の組織診断別では CPH 8 例中 7 例 (87.5\%)，

CAH2A 19例中11例 (57.9\%), CAH2B 3 例中 1 例 (33.3\%) において治療終了時の肝組織中 HCV-RNA は陰性化し，組織学的進展度が軽度の症例に肝組織中 HCV-RNA の陰性例が多くみられたが, 有意差は認め られなかった。 また, HCV の genotype との関連では, II 型20例中 11 例 $(55 \%)$ ，III型 2 例中 1 例 (50\%), IV 型 2 例中 1 例 $(50 \%)$ において肝組織中 HCV.RNAの 


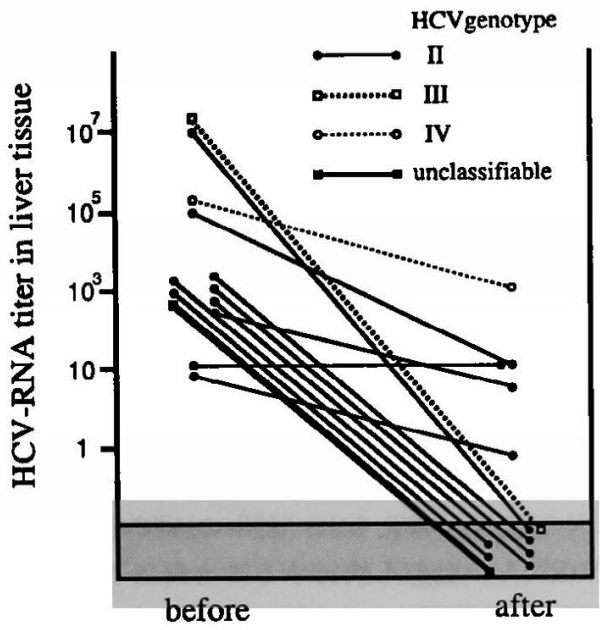

Fig. 1 Comparison of HCV-RNA titers in liver tissue before and after IFN therapy.; Assays were carried out by 10 -fold serial dilutions of RNA from liver tissue specimen. The shadowed area indicates negative HCV-RNA in the specimen examined.

陰性化を認めた，さらに，治療前ウイルス量との関連 では，肝生検検体当たり $10^{3}$ 希䣋以下の，ウイルス量の 比較的少ない群では 9 例中 6 例 $(66.7 \%)$ に HCVRNAの陰性化を認め, 一方 $10^{5}$ るいは107希釈以上の 4 例では 2 例（50\%）に HCV-RNA の陰性化を認め た.

2. IFN 治療終了時の肝組織中 HCV-RNA と治療 効果

対象とした30例の IFN 治療効果は著効 8 例 (26.7\%), 有効 8 例(26.7\%)，不変あるいは悪化14例 （46.7\%）であった（Table 1)．治療終了時の血中 HCV-RNA との関連では，血中 HCV-RNA は，著効 8 例では全例陰性であったが, 有効 8 例中 6 例(75\%)， 不変あるいは悪化14例中11例（78.6\%）においても陰 性化を認め，治療効果にかかわらす陰性化率は高率で あった。

一方, 治療終了時の肝組織中 HCV-RNA と治療効 果との関連では，肝組織中 HCV-RNA は著効 8 例で は全例，有効 8 例では 3 例( $37.5 \%)$ ，不変あるいは悪 化の14例では 8 例（57.1\%）が陰性であり，著効例に おける陰性化率が高く，その差は有意であった( $\mathrm{p}<$ 0.05)，また，治療効果を治療終了時の HCV-RNA 測 定結果から検討すると，IFN 終了時に肝組織中 HCVRNA が陽性であった11例には著効例を認めず，治療
Table 3 Response to IFN in patients who were negative for HCV-RNA in serum at the end of therapy.

\begin{tabular}{c|c|c|c|c|c}
\hline \multicolumn{2}{c|}{ HCV-RNA } & \multirow{2}{*}{ No. } & \multicolumn{3}{|c}{ Response to IFN } \\
\cline { 1 - 4 } serum & liver & & excellent & good & no response \\
\hline \multirow{2}{*}{$(-)$} & $(+)$ & 6 & 0 & 2 & 4 \\
& $(-)$ & 18 & 8 & 3 & 7 \\
\hline
\end{tabular}
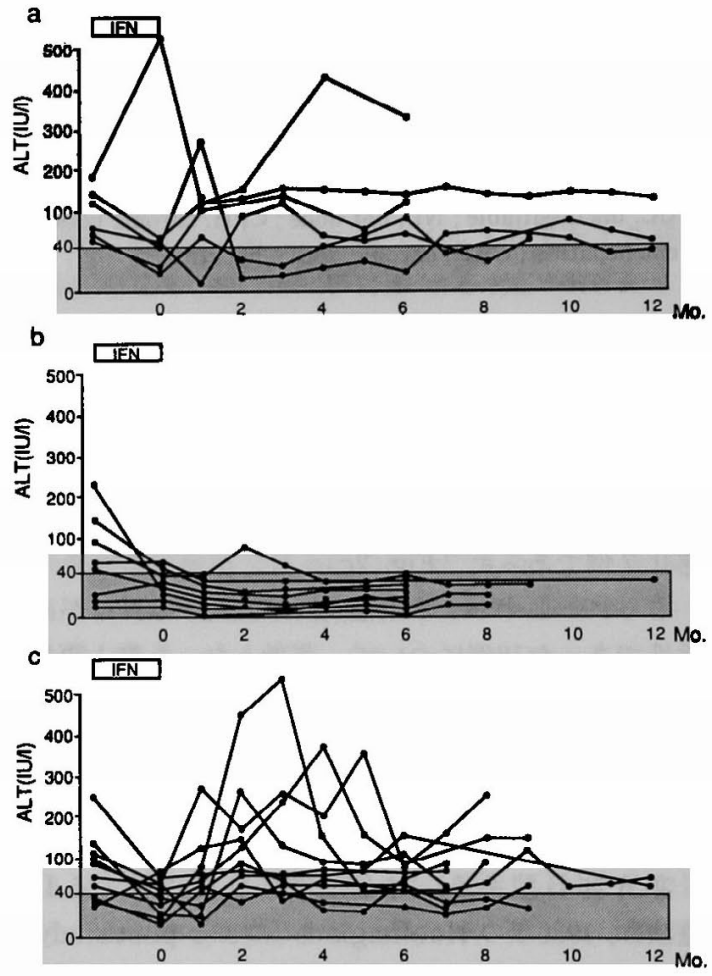

Fig. 2 Serial changes of serum ALT levels in patients with chronic hepatitis $\mathrm{C}$ treated with IFN. ; (a) patients who were negative for $\mathrm{HCV}$. RNA in serum but positive in liver tissue at the end of IFN therapy. (b) excellent responders who were negative for HCV-RNA in both serum and liver tissue at the end of therapy. (c) good or non-responders who were negative for $\mathrm{HCV}$. RNA in both serum and liver tissue at the end of therapy.Mo., months.

終了時に肝組織中 HCV·RNA が陰性の19例では，著 効 8 例 $(42 \%)$, 有効 3 例 $(15.8 \%)$ ，不变あるいは悪 化 8 例 (42\%) であった。

次に，治療終了時の血中 HCV-RNA 陰性例24例に おいて, 肝組織中 HCV.RNA 別に治療効果を検討し 
Table 4 Clinicopathological and genetical features of "excellent" and "non-excellent" responders for IFN therapy who were negative for HCV-RNA in both serum and liver tissue.

\begin{tabular}{c|c|c}
\hline Response to IFN & Excellent & Non-excellent \\
\hline No. & 8 & 10 \\
IFN $(\alpha / \beta)$ & $5 / 3$ & $2 / 8$ \\
age & $41.4 \pm 11.1$ & $51.2 \pm 10.6$ \\
male/female & $7 / 1$ & $7 / 3$ \\
blood transfusion ( $+/-)$ & $4 / 4$ & $5 / 5$ \\
s-ALT (IU / $l$ ) & $75.3 \pm 71.0$ & $87.6 \pm 59.2$ \\
genotype & $4 / 0 / 0 / 2 / 2$ & $6 / 1 / 1 / 2 / 0$ \\
(II/III/IV/UC/ND) & $3 / 5 / 0$ & $3 / 6 / 1$ \\
liver histology & & \\
(CPH/CAH2A/CAH2B) & & \\
\hline
\end{tabular}

$\mathrm{UC}$, unclassifiable ; ND, not done ; $\mathrm{CPH}$, chronic persistent hepatitis ; $\mathrm{CAH}$, chronic active hepatitis.

た(Table 3).血中陰性で肝組織中に HCV-RNA が検 出された 6 例では，全例経過中にALT 值の上昇を認 めた（Fig. 2a)。一方, IFN 治療終了時に血中・肝組 織中ともに HCV-RNAが陰性となった18例では，著 効例は 8 例であり (Fig. 2b)，有効 3 例，不变あるいは 悪化 7 例であった（Fig. 2c).

さらに，血中および肝組織中の HCV-RNAが両者 陰性であった18例について，著効となった群と再燃を 認めた群に分け，その臨床・ウイルス学的背景を比較 検討したが明らかな差は認められなかった（Table 4).

\section{考 察}

非 A 非 B 型あるいはC 型慢性肝炎に対する IFN 療法は, 1986年の Hoofnagle ら"1による pilot study 以 来，その有効性が数多く報告されてきた。しかし，IFN の投与により治療終了時には血清 ALT 值の正常化と 血中 HCV-RNA の陰性化を高率に認めるものの，释 過観察中，約50\%に血清 ALT 值の一過性あるいは持 続的な上昇を認めることが知られている5

今回の検討においても，治療終了時には30例中20例 (66.7\%) と高率に血清 ALT 值が正常值を示し，治療 終了時の血中 HCV-RNA 陰性例も24例 (80\%) と高率 であった，しかし，多くの例で再然を認め，治療後の 血清 ALT 值の推移上り著奻之診断しえたのは 8 例 （26.7\%）にすぎなかった。

萩原 ら5は は 型慢性肝炎患者を対象に IFN 療法を 行い，その前後で血中 HCV-RNA を測定し，治療効果 との関連について検討した。彼らは，18例中16例 （88.9\%）において治療終了時の血中 HCV-RNA が陰
性化したものの，そのうち12例（75\%）に再然を認め たことから，血中 HCV-RNAの変動様式からの治療 終了後の経過予測には限界があったとし，PCR 法の感 度の向上による検討とともに，ウイルス增殖の場であ る肝組織中における HCV-RNA の変動む検討する必 要があることを報告した。

HCV が肝組織中で增殖していることは，肝組織中 に HCVのプラス鎖 RNAのみでなく，増殖中間体と されるマイナス鎖 RNA 検出されることから確認さ れている ${ }^{12)}$. したがって，IFN 治療によりウイルス血 症が消失しても，旰組織中に HCV が残存し，再然に結 びつく可能性が考えられ，血中のみでなく肝組織中 HCV-RNA の動態も検討することにより，IFN 療法 の抗ウイルス効果をより詳細に解析できるるのと思わ れる.

IFN 療法後の血中および肝組織中 HCV-RNAの模 出率や治療効果との関連については，これまでいくつ かの報告がなれてきたが，未だ一定の見解は得られ ていない，松本ら ${ }^{(3)}$ は14例のC型慢性肝炎患者に 48 560MU の IFN 投与を行い，治療終了時の血中拧 よび肝組織中 HCV-RNA と治療終了後 3 カ月までの 治療効果を検討した。彼らは，IFN 治療終了時の HCV-RNA 検出率は血中では14例中 4 例 (28.6\%) で あったが，肝組織中では14例すべてに検出されたと報 告した。また，肝組織中 HCV-RNA と治療効果との関 連については，治療終了時の肝組織中 HCV-RNA は 治療効果にかかわらず全例に陽性であり，しかも治療 終了時のウイルス量は有効例と無效例との間に有意差 は認められず，両群とも著明に低下したため，治療後 の ALT 值の推移を予測することはできなかったと報 告した. 一方, Balart ら ${ }^{14}$ は21例に $\alpha$-IFN 療法を行っ たところ，IFN 治療終了時の HCV-RNA 検出率は血 中では21例中 9 例( $42.9 \%)$ ，肝組織中では21例中 6 例 (28.6\%)であり，肝組織中の検出率が血中上り高率で はなかったと報告した。 また，治療終了時の $\mathrm{HCV}$. RNA と治療効果との関連を検討すると, complete response 群11例中，治療終了時に血中 HCV-RNA 陽 性であったものは 1 例, 肝組織中 HCV-RNA 陽性で あったるのは1例であり， partial response群拉よび no response 群の合計10例では血中で 8 例, 肝組織中 では 5 例にのみ HCV-RNAが陽性であった。した がって，血中のみならず，肝組織中 HCV-RNA まで埃 討しても，治療効果予測は困難であったと報告した，

今回の検討では，IFN 治療終了時の HCV-RNA 検 
出率は血中では30例中 6 例 $(20 \%)$, 肝組織中では 30 例 中11例 (36.7\%) であった。治療終了時の肝組織中に おける HCV-RNA の陽性率は血中より高かったか， 有意差は認められなかった，今回の治療終了時の肝組 織中 HCV-RNA 陽性率はBalart らの報告之近似す るすのの，松本らの報告とは大きく異なる，その理由 として，松本らの報告においては，IFN 総投与量が14 例中 8 例において ウイルス効果が充分ではなく，治療終了時においても 肝組織中 HCV-RNA 陰性化例が認められなかった可 能性が考えられる。亦た今回，治療終了時の $\mathrm{HCV}$ 。 RNA と治療効果との関連では，著効例 8 例はすへて 血中および肝組織中 HCV-RNA 陰性であったが，非 著奻例22例では治療終了時の血中 HCV-RNA 陽性が 6 例 (27.3\%), 肝組織 中 HCV.RNA 陽性 が11例 (50\%)であった，以上の結果より，著効を得るために はIFN 終了時に肝組織中 HCV-RNAが陰性化する 必要があると考えられたが，それです充分とはいえず， Balart らの報告と同様に, 治療終了時に肝組織中 HCV-RNA が陰性となった例であっても再然を多く 認めた。したがって，今後はIFN 療法例が著効を得る には，血中あるいは肝組織中 HCV-RNA の陰性化を 目標とするだけでなく，陰性化した時点よりさらに長 期の IFN 投与す考える必要があるるのと思われた.

今回, 治療終了時の血中 HCV.RNA と肝組織中 HCV-RNAの関連では，治療終了時に血中 HCVRNA が陰性となった24例中 6 例（25\%）に肝組織中 HCV-RNA が陽性でありこれら全例が経過観察中に 血清 ALT 值の上昇を認めた。この上らな症例では， IFN 治療によりウイルス血症が消失したものの, 肝組 織中に HCV が残存し，治療終了後に再然を示したも のと考えられた。しかし，血中のみでなく肝組織中む HCV-RNA が陰性化した18例であっても，10例(56\%) に再然を認めた。 この理由として，(1) 肝生検サンブ ルが極めて少量であること，(2) PCR 法の感度が低い こと，(3）肝以外に HCV のリザーバーとなる場が存 在すること，の3つの可能性が考えられる。肝組織中 における HCV 量は単位重量あたり血清の約100倍と の報告(5) すうり，より高感度に測定できることが期待 されるすのの, 本論文では $5 \mathrm{~mm}$ 長の検体(体積約 $4 \mu l$ ) の半量と，極めて少量より検出を行ったため，測定感 度に影掣を与えた可能性が考点られる。 また肝生検組 織が少量の場合には、サンプリンクの場所によりサン プル中の $\mathrm{HCV}$ 量に多宾が生じる可能性も考えられ
Ђ ${ }^{14)}$.

PCR 法の感度については，nested PCR 法では 1 コ ピーの CDNAさ之検出可能であり高感度とされてい るが16)，cDNA 合成までの段階，つまり RNA 調整時 の口スや逆転写反応の効率が問題となり測定感度が充 分ではなかった可能性る考之られる5゙.

肝以外のリザーバーについては，B 型肝炎ウイルス DNA が血中や肝のみならずリンバ節・脾・生殖器・甲

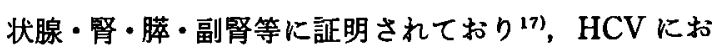
いても肝以外に増殖を認める臓器や組織が存在する可 能性も否定できないと思われる。史た，近年 HBVのみ ならず $\mathrm{HCV}$ す末梢血単核球 (PBMC) に検出される との報告がされている(8,19).

今後, IFN 治療施行例の抗ウイルス効果をより詳細 に解析するには, PBMCにおける HCV-RNA と血 中・肝組織中の HCV-RNA の関連や IFN 治療効果と の関連につき，さらに検討を要するものと思われる。 またこれまで HCV 感染肝細胞の検出に in situ hybridization 法を用いた方法が娭討されてきたか， PCR 法の併用 (PCR-in situ hybridization 法)により， より高感度に愉出できるとの報告201るある.今後はこ のよらに新たな高感度検出法も検討されるべきである 5と思われる。

また, IFN 治療終了時の肝組織中 HCV-RNA 陰性 化例における著効の条件を明らかにするため，今回の 検討において、IFN 治療終了時に血中および肝組織中 ともに HCV-RNA が陰性であった18例について, 著 効となった 8 例と再然を認めた10例に分け，その臨 床・ウイルス学的特徽を検討したが，明らかな差は見 いだしえなかった．今後はこうした両者陰性例のうち どのよらな症例が著効となり，どのような症例が再然 するのかを明らかにすることが治療効果予測上重要で あり，IFN 投与スケシュールを適宜変更することによ り、上り㚳率のよい治療を行える可能性す考えられる.

本研究により, IFN 治療終了時に血中 HCV-RNA が陰性となった例でも，その約 $1 / 4$ に肝組織中 $\mathrm{HCV}$ RNAが検出されることが明らかとなった.さらに、こ のような例では全例経過観察中に再燃を認め, 著効之 なるには，治療終了時に血中のみでなく肝組織中の HCV-RNA む陰性化する必要のあることが示された。 しかし，血中および肝組織中 HCV-RNAが両者陰性 化してもなお効果予測には限界があり, 約半数の例に 再然か認められた。今啳はIFN 治療例の抗ウイルス効 果を正確に評価するらえで，より多くのウイルス学的 
知見の集積が必要之考えられ，その成果によりC型慢 性肝炎に対するIFN 潦法が，上り効率よく行われるこ とが期待される。

$$
\text { 結 語 }
$$

IFN 療法を施行した 30 例のC 型慢性肝炎症例を対 象に治療前後で血中おょび肝組織中 HCV-RNA を測 定し，治療効果との関連について検討し，以下の結果 を得た。

1）治療前には，血中 HCV-RNA は29例 (96.7\%), 肝組織中 HCV-RNA は測定した14例すべてに陽性で あった，治療終了時には，血中 HCV-RNAは 6 例 (20\%)，肝組織中 HCV-RNA は11例 (36.7\%) に検出 され，肝組織中に打る陽性率が高かったものの有意 差は認められなかった。

2) 治療前後で肝組織中 HCV-RNA 量を測定した 13例では，12例にウイルス量の減少が認められ，IFN の抗ウイルス効果が示された。

3) IFN 治療終了時, 血中 HCV.RNA 陰性の24例中 6 例 (25\%) に肝組織中 HCV-RNA が陽性であり，ウ 1ルス血症消失後も肝組織中心 HCV の残存する例が 存在することが明らかとなった。これらの6 例では経 過観察中に全例再然を認め，著効となるためには少な くとも肝組織中 HCV-RNA をで陰性化する必要があ るものと考えられた。

4）治療終了時に血中・盰組織中とも K HCV-RNA が陰性の18例では著効は8 例 (44\%) にすぎず，両者 陰性例であっても再然例を多く認めた。したがって， 血中のみでなく肝組織中 HCV.RNA まで測定して も，治療効果予測にはなお限界があるすのと思われた。

謝辞：本稿を終えるにあたり，終始御留篤なる御指導と 御校閲を賜った恩師小林健一教授に深甚の謝意を表しま

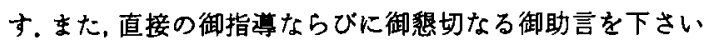
ました䴔浦雅志講師，金子周一缕師に深謝致します。拉よび 本研究に御協力下さいました金沢大学医学部第 1 内科第 2 研究室各位に感謝の意を表します。

この論文の要旨は, 第29回日本肝荗学会総会 (1993年, 奈 良)において発表した。

$$
\text { 文献 }
$$

1) Hoofnagle $\mathrm{JH}$, Mullen $\mathrm{KM}$, Jones $\mathrm{DB}$, et al: Treatment of chronic non-A,non-B hepatitis with recombinant human alpha interferon. A preliminary report. N Engl J Med 315: 1575 $-1578,1986$
2) Thomson BJ, Doran M, Lever AML, et al: Alpha-interferon therapy for non-A,non-B hepatitis transmitted by gammaglobulin replacement therapy. Lancet 1:539-541, 1987

3) Davis GL, Balart LA, Schiff EF, et al: Treatment of chronic hepatitis $\mathrm{C}$ with recombinant interferon alpha: A multicenter randomized controlled trial. N Engl J Med 321 : 1501-1506, 1989

4) Di Bisceglie AM, Martin P, Kassiandies C, et al: Recombinant interferon alpha therapy for chronic hepatitis C. N Engl J Med 321: 1506 $-1510,1989$

5）萩原秀紀，林 紀夫，三田英治，他：Interferon 治 療時の血中 C 型肝炎ウイルス RNA の検討. 日消 誌 88(7): 1420-1425, 1991

6) Chayama K, Saitoh $S$, Arase $Y$, et al : Effect of interferon administration on serum hepatitis $C$ virus RNA in patients with chronic hepatitis C. Hepatology 13: 1040-1043, 1991

7）赤羽賢浩, 岡田俊一，宮崎吉規，他：C型肝炎に対 する interferonの短期投与の抗ウイルス効果. 肝 䁍 32(3) : 243-249, 1991

8）矢野右人, 八橋 弘, 井上長三, 他：DNA ブロー ブ法による肝炎ゥイルスのゲ/ム診断。肝眮 33(Suppl 1): 49, 1992

9）金子周一，三谷隆彦：臨床ウイルスマーカーとし てのC 型肝炎ウイルス RNA 測定の可能性. 肝瞊 34(7) : 579-581, 1993

10) Okamoto H, Sugiyama $Y$, Okuda $S$, et al: Typing hepatitis $\mathrm{C}$ virus by polymerase chain reaction with type-specific primers: Application to clinical surveys and tracing infectious sources. J Gen Virol 73: 673-679, 1992

11) Chomczynski P, Sacchi N : Single-step method of RNA isolation by acid guanidium thiocyanate-phenol-chloroform extraction. Analytical Biochemistry 162:156-159, 1987

12) Fong TL, Shindo $M$, Feinstone $S M$, et al: Detection of replicative intermediates of hepatitis $C$ viral RNA in liver and serum of patients with chronic hepatitis $\mathrm{C}$. J Clin Invest $88: 1058$ $-1060,1991$

13）松本昌之，藤森 功，奥野忠雄，他：C 型慢性肝炎 のインターフェロン治療に上る肝内および血中 HCV RNAレデルの变化. 肝蔵 32(11)：983 
$-989,1991$

14) Balart LA, Perrillo R, Roddenberry J, et al : Hepatitis C RNA in liver of chronic hepatitis C patients before and after interferon alfa treatment. Gastroenterology 104 : 1472-1477, 1993

15）八橋 弘, 矢野右人: HCV-RNA level $と \mathrm{HCV}$ genotype の臨床的有用性. 肝缄 34(Suppl 1): 54, 1993

16) Garson JA, Tedder RS, Briggs $M$, et al : Detection of hepatitis $C$ viral sequences in blood donations by "nested" polymerase chain reaction and prediction of infectivity. Lancet 335 : 1419-1422, 1990

17) Yoffe B, Burns DK, Bhatt HS, et al: Extrahe- patic hepatitis $B$ virus DNA sequences in patients with acute hepatitis $B$ infection. Hepatology $12: 187-192,1990$

18) Mueller HM, Pfaff E, Theilmann L : Detection of $\mathrm{HCV}$ RNA in lymphocytes derived from chronically infected patients using the polymerase chain reaction. Hepatology, 14:67A, 1991

19）柳昌幸, 佐伯理恵子, 竹内正勇, 他：患者末梢血 リンハ:球からの HCV-RNAの検出. 肝蔵 33(Suppl 2) : 50, 1992

20）河合博志, 金子周一, 中本安成, 他：Polymerase chain reaction in situ hybridization (PCR ISH) 法による HCV 感染肝細胞の検出。肝䐵 34(Suppl 1) : 228, 1993

\section{Change of HCV-RNA in liver tissue and interferon responsiveness in patients with chronic hepatitis $\mathrm{C}$}

\section{Masayu TAKEUCH*}

In order to clarify the relationship between the change of HCV-RNA in liver tissue and response to IFN therapy, HCV-RNA in sera and liver tissues of 30 patients with chronic hepatitis $\mathrm{C}$ were examined before and after IFN therapy. Before therapy, serum HCV-RNA were detected in 29 out of 30 (96.7\%) patients, and liver tissues of all 14 patients examined were positive for HCV-RNA. At the end of IFN therapy, serum HCV-RNA was still positive in $6(20 \%)$ patients and liver tissues of $11(36.7 \%)$ patients contained HCV-RNA. Comparison of HCV-RNA levels in liver tissues of 13 patients before and after IFN therapy revealed that the viral titers decreased following therapy in all cases except one. As for the relationship between the change of HCV.RNA presence and the therapeutic effect, relapse was observed in all the patients who had been positive for HCV-RNA in liver tissue at the end of IFN therapy. Even among 18 patients who were negative for HCV-RNA in both serum and liver tissue, only $8(44 \%)$ patients showed an excellent response to IFN therapy. These results indicate that the relapse is observed in all of those patients in whom HCV-RNA became negative in serum but was still positive in liver tissue at the end of therapy, and that there are also some cases who show relapse even after disappearance of HCV-RNA from liver tissue.

\footnotetext{
* First Department of Internal Medicine, Kanazawa University School of Medicine (Kanazawa)
} 